\title{
Fear of COVID-19 scale: validation in Spanish in the Mexican general population
}

\author{
Alejandro I. Soto-Briseño, Rita A. Gómez-Díaz²*, Adriana L. Valdez-González², \\ Ricardo C. Saldaña-Espinoza², José J. Favila Bojórquez' and Niels H. Wacher ${ }^{2}$ \\ ${ }^{1}$ Psychiatry Department; ${ }^{2}$ Clinical Epidemiology Research Unit. High Specialty Medical Unit, Specialty Hospital, Centro Médico Siglo XXI, Instituto \\ Mexicano del Seguro Social, Mexico City, Mexico
}

\begin{abstract}
Introduction: The fear of COVID-19 scale (FCV-19S) is used to screen for symptoms of anxiety and depression related to COVID-19 in the general population; it consists of seven questions with Likert-type answers (1-5). Our objective was to validate FCV-19S Spanish version in the Mexican general population. Material and methods: Analytical, cross-sectional design. Three-hundred and six subjects from the general population were included during 2020 after having signed informed consent. Barlett and Kaiser-Meyer-Olkin (KMO) sphericity tests were applied. Reliability was calculated with Cronbach's alpha, and external validity, using the Hospital Anxiety and Depression Scale and Pearson's correlation coefficient for retest. Results: The general population sample included 306 participants; $64.4 \%$ were women $(n=197)$, mean age was 32 years $(18-68)$. We obtained a $K M O=0.848$, internal consistency with Cronbach's alpha $=0.870$ (95\% Cl: 0.848-0.891), a rho coefficient of 0.508 $(p<0.001)$ and external validity of $0.151(p=0.008)$. Confirmatory analysis showed: $\chi^{2}=22.802(d f=13)$ with CMIN$D F=1.900(p \leq 0.001), G F I=0.972, C F I=0.901, R M S E A=0.062(90 \% \mathrm{Cl}: 0.019-0.100)$ and $T L I=0.827$. Conclusions: $A c-$ cording to our findings, the scale shows adequate psychometric properties: reliability, internal consistency, correlation with subsequent measurements and convergence validity, for initial screening of the Mexican general population.
\end{abstract}

KEY WORDS: COVID-19. Fear of COVID-19 scale. Spanish. Psychometrics. Mexico.

\section{Escala de temor a la COVID-19: validación de la versión en español en la población mexicana}

\section{Resumen}

Introducción: La Escala de temor a la COVID-19 (FCV-19S) se usa en el tamizaje de síntomas de ansiedad y depresión relacionados con la COVID-19 en población general; consta de siete preguntas con respuestas tipo Likert (1-5). Nuestro objetivo fue validar la versión del FCV-19S en la población general mexicana. Material y métodos: Diseño transversal analítico. Se incluyeron 306 sujetos de la población general durante 2020 con firma previa de consentimiento informado. Se aplicaron pruebas de esfericidad de Barlett y Kaiser-Meyer-Olkin (KMO). Se calculó la confiabilidad con el alfa de Cronbach, la validez externa utilizando la Escala hospitalaria de ansiedad y depresión y el coeficiente de correlación de Pearson para retest. Resultados: La muestra de la población general incluyó a 306 participantes, el 64.4\% mujeres ( $n=197)$, edad media 32 años (18-68). Obtuvimos un $K M O=0.848$, consistencia interna con alfa de Cronbach $=0.870$ (IC 95\%: 0.848-0.891), coeficiente rho de $0.508(p<0.001)$ y validez externa de $0.151(p=0.008)$. El análisis confirmatorio mostró: $\chi^{2}=22.802(d f=13)$ con $C M I N-D F=1.900, p \leq 0.001, G F I=0.972, C F I=0.901, R M S E A=0.062$ (IC 90\%: 0.019-0.100) y TLI=0.827. Conclusiones: $L a$ FCV-19S demuestra propiedades psicométricas adecuadas (confiabilidad, consistencia interna, correlación con mediciones subsecuentes y validez de convergencia) para su aplicación en la población general mexicana.

PALABRAS CLAVE: COVID-19. Escala de temor a COVID-19. Español. Psicométricos. México.

\footnotetext{
Correspondence:

Date of reception: 05-03-2021

*Rita A. Gómez-Díaz

Date of acceptance: $07-10-2021$

Gac Med Mex. 2021;157:566-573

E-mail: ritagomezdiaz@yahoo.com.mx

DOI: $10.24875 / G M M . M 21000618$

Contents available at PubMed license (http://creativecommons.org/licenses/by-nc-nd/4.0/).
} 


\section{Introduction}

Considering the cases of pneumonia associated with severe acute respiratory syndrome coronavirus 2 (SARS-CoV-2) and its disease, the COVID-19 pandemic constitutes a public health problem with varying rates of morbidity and mortality ${ }^{1-3}$.

According to the General Directorate of Epidemiology, in our country we have 2,175,662 accumulated confirmed cases of COVID-19 (49.9\% women) by the first half of March 2021, which corresponds to $1.726 \%$ of the 126,014,024 inhabitants of our country according to the latest report from the National Institute of Statistics and Geography (INEGI - Instituto Nacional de Estadística y Geografía) ${ }^{4}$. A total of 32,206 active cases are reported, among which $18.71 \%$ require in-hospital treatment; main associated comorbidities are hypertension (17.31\%), obesity $(14.45 \%)$, diabetes mellitus (13.35\%) and smoking (7.35\%); in addition, 195,908 accumulated deaths are reported ${ }^{5-7}$. During the months of January to August 2020, COVID-19 was the second cause of death in our country ${ }^{8}$.

There is fear and concern of contact with other people due to the risk of infection by SARS-CoV-2, of developing severe forms of COVID-19, of the possibility of requiring mechanical ventilation, or losing loved ones or dying. Social distancing measures are essential for reducing infection rates; however, they are associated with symptoms of anxiety and depression that especially affect vulnerable groups such as pregnant women, children, people with physical or mental disabilities and older adults ${ }^{9,10}$.

The fear of COVID-19 scale (FCV-19S) is an instrument used for the detection of fear related to COVID-19 in the general population, which identifies symptoms of anxiety and depression related to this pandemic. It consists of seven elements, with Likert-type responses (1-5) and scores that range from 7 to 35 . The higher the score, the greater the fear related to COVID-19. This instrument has shown internal consistency in its original version, with $\alpha=0.82$, and test-retest reliability (intra-class correlation coefficient $=0.72)^{11}$. So far, several versions have been validated, and internal consistency has been reported in several languages, such as Italian $(\alpha=0.87)^{12}$, Russian $(\alpha=0.81)^{13}$, Turkish $(\alpha=0.85)^{14}$, Arabic $(\alpha=0.88)^{15}$, Hebrew $(\alpha=0.86)^{16}$, Bengali $(\alpha=0.87)^{17}$, Malayan $(\alpha=0.89)^{18}$, Romanian $(\alpha=0.88)^{19}$, Portuguese $(\alpha=0.88)^{20}$, Japanese $(\alpha=0.87)^{21}$, Greek $(\alpha=0.83)^{22}$ and English $(\alpha=0.84$ and 0.86 in different samples) ${ }^{23}$.
In Spanish, it has been validated in the general population in Peru ( $n=832$; mean age: $38.37 \pm$ 12.75 years), with an $\alpha=0.8724$, and in university students aged 18 to 40 years in Spain $(n=606$; mean age: $21.59 \pm 3.04$ years), with an $\alpha=0.86^{25}$.

In our country, the FCV-19S has been used to measure fear related to COVID-19 in health workers (with an $\alpha=0.92$ ); however, convergence measurements were not carried out ${ }^{26}$.

Taking the above into account, our purpose was to validate the FCV-19S Spanish language version in the Mexican general population.

\section{Material and methods}

In this study, the FCV-19S original version was translated into Spanish by an independent certified bilingual translator with extensive experience in clinical areas, and subsequently was reviewed by two independent bilingual translators in order for its characteristics (intelligibility and accuracy) to be confirmed, and back-translation was finally carried out.

The study population was the general population of Mexico City, with a convenience sampling strategy being used. Recruitment was carried out through social networks; 306 participants aged 18 to 80 years were included, after having signed and emailed an informed consent for participating. The information was collected from August through November 2020, by means of telephone calls when social distancing measures were established nation-wide in order to reduce the risks of infection among participants and medical personnel.

Sociodemographic information was collected, including age, gender, marital status, level of education and socioeconomic status.

To determine FCV-19S convergent validity in the original version, the Hospital Anxiety and Depression Scale (HADS), which has been previously validated in our country, was used ${ }^{25,26}$.

\section{Statistical analysis}

Descriptive statistics was used for FCV-19S elements (main elements' mean and standard deviation) and a polychoric matrix of its seven elements was generated; factor analysis was carried out using Bartlett's sphericity test and the Keizer-Meyer-Olkin (KMO) test. FCV-19S Spanish language version validity criterion was determined with Pearson's correlation coefficient using HADS. Reliability of the scale was 
examined using composite reliability (CR), and global score internal consistency was calculated using Cronbach's alpha coefficient. Goodness-of-fit of the model was examined with the following indices: goodnessof-fit index (GFI), chi-square test $\left(\chi^{2}\right)$, degrees of freedom (df), root mean square error of approximation (RMSEA), comparative fit index (CFI), standardized root mean residual (SRMR) and Tucker-Lewis index (TLI). The analysis was carried out using SPSS, v.23.0 (IBM Corp., Armonk, NY), FACTOR, v.10.10.03 (Ferrando and Lorenzo-Seva, Universitat Rovira i Virgili), and IBM SPSS AMOS, v.23 (IBM Corp., Armonk, NY).

\section{Results}

\section{Sociodemographic characteristics}

The general population sample included 306 participants ( $n=197,64.4 \%$ women), with a mean age of 32 years (18-68); when grouped by age, the highest percentage (44.4\%) was between 30 and 39 years of age. Regarding educational level, we distributed the results into five groups and, as regards marital status, we found that $21.8 \%$ were single, $49.4 \%$ married, $9.8 \%$ divorced and $18.9 \%$ were cohabitating (Table 1).

\section{FCV-19S Spanish language version psychometric analysis}

FCV-19S total mean score was 17.63 (standard deviation $[S D] \pm 6.60$ ) (Table 2). A t-test for independent samples was carried out to compare FCV-19S scores between women 19.09 (SD \pm 6.67 ) and men 14.99 (SD \pm 5.62 ), with a significant difference being found $(\mathrm{t}=-4.01 ; \mathrm{p}<0.001)$.

All seven FCV-19S questions (Fig. 1) were asymmetrically distributed, with the highest frequencies being observed in the lower ranges, except for questions 1 and 7, with a non-normal distribution (Kolmogorov-Smirnov test, $p<0.001$ ).

Exploratory factor analysis was carried out in 70 randomly selected participants, with a $\mathrm{KMO}=0.848$ being obtained (95\% confidence interval [ $\mathrm{Cl}]$ : 0.848 0.891); Barlett's sphericity test was significant $\left(\chi^{2}: 272.0 ; p<0.001\right)$, which indicates that the factor analysis is pertinent for the data set. All the elements were statistically significant for the polychoric correlation (min: 0.258, max: 0.727, $p<0.001$ ) (Table 3).

Analysis of the main components extracted one component with an eigenvalue (4.2744) that explained
Table 1. Sample characteristics $(\mathbf{n}=\mathbf{3 0 6})$

$\begin{array}{lll}\text { Gender } n=306(\%) & \text { Educational level } & \text { Marital status } \\ \text { Females 197 (64.4) } & \text { Primary school 6 (2.0) } & \text { Single 67 (21.8) } \\ \text { Males 109 (35.6) } & \text { Secondary school 51 } & \text { Married 151 (49.4) } \\ \text { Age (years) (\%) } & (16.7) & \text { Divorced 30 (9.8) } \\ \text { 18-29 126 (41.1) } & \text { High school 78 (25.5) } & \text { Cohabitating 58 } \\ 30-39136(44.4) & \text { College degree 126 } & (18.9) \\ 40-4931(10.1) & (41.1) & \\ 50-5911(3.5) & \text { Post-degree 12 (3.9) } & \\ \geq 602(0.7) & \text { None 8 (2.6) } & \\ & \text { Did not answer 25 (8.2) } & \end{array}$

Table 2. Descriptive analysis of the seven questions of the Fear of COVID-19 Scale Spanish language version

\begin{tabular}{|l|l|c|c|c|c|}
\hline & Mean & $\begin{array}{c}\text { 95\% confidence } \\
\text { interval for the } \\
\text { mean }\end{array}$ & Variance & Bias & Kurtosis \\
\hline Item 1 & 2.96 & $2.77-3.14$ & 1.363 & -0.328 & -0.937 \\
\hline Item 2 & 2.44 & $2.25-2.63$ & 1.466 & 0.308 & -1.062 \\
\hline Item 3 & 1.72 & $1.58-1.86$ & 0.741 & 0.943 & -0.048 \\
\hline Item 4 & 2.57 & $2.36-2.79$ & 1.874 & 0.201 & -1.352 \\
\hline Item 5 & 2.57 & $2.37-2.78$ & 1.708 & 0.222 & -1.202 \\
\hline Item 6 & 1.77 & $1.62-1.92$ & 0.947 & 1.237 & 1.085 \\
\hline Item 7 & 2.19 & $2.01-2.37$ & 1.335 & 0.528 & -0.815 \\
\hline
\end{tabular}

$61 \%$ of the variance. Factor load of all questions ranged between 0.519 and 0.869 , with commonality being higher than 0.3 (Table 4).

Subsequently, confirmatory factor analysis was carried out with 236 participants, different from those used for the exploratory factor analysis, using the AMOS program. Several models were analyzed in order to identify the one that best fitted the recommended validation indices. Confirmatory factor analysis model 1 had all seven questions, and error deviations were not correlated. RMSEA value was 0.090 , which is within the values established as satisfactory (Fig. 2). In our Spanish language validation, we found an interrelation between questions 3 (my hands become clammy when I think about coronavirus-19) and 6 (I cannot sleep because I'm worrying about getting coronavirus-19), and the lowest scores, which is why model 2 was generated taking into account the error variation (Fig. 3); in addition, we found an interrelation between questions 6 (I cannot sleep because I'm worrying about getting coronavirus-19) and 7 (my heart races or palpitates when I think about getting coronavirus-19), 

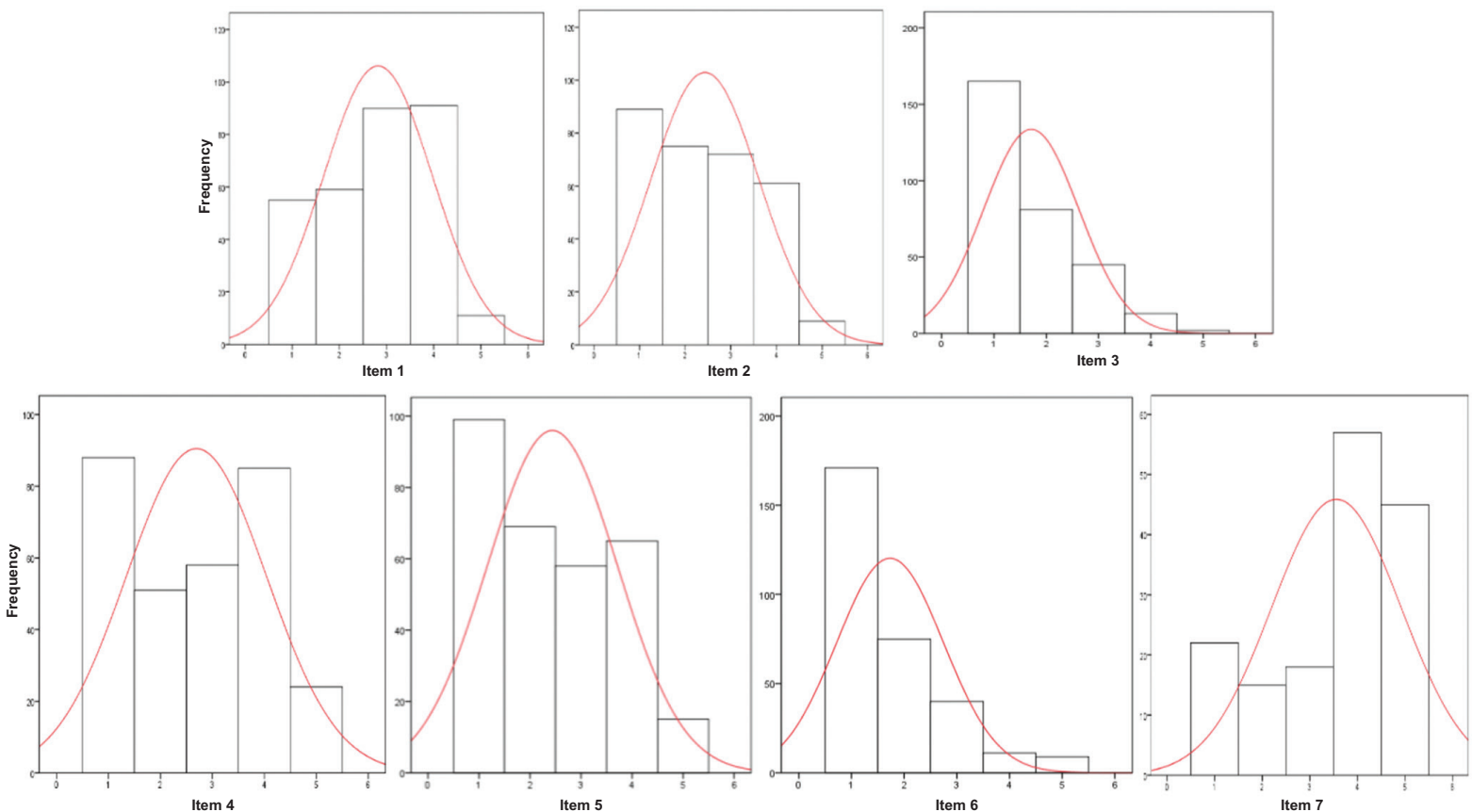

Figure 1. Histograms for the seven questions of the Fear of COVID-19 Scale Spanish language version (the red lines show the curve normal distribution).

Table 3. Variance/covariance standardized matrix (polychoric correlation)

\begin{tabular}{|c|c|c|c|c|c|c|c|}
\hline Correlations & Question 1 & Question 2 & Question 3 & Question 4 & Question 5 & Question 6 & Question 7 \\
\hline Question 1 & 1.000 & & & & & & \\
\hline Question 2 & $0.500^{*}$ & 1.000 & & & & & \\
\hline Question 3 & $0.425^{\star}$ & $0.711^{*}$ & 1.000 & & & & \\
\hline Question 4 & $0.552^{*}$ & $0.450^{*}$ & $0.367^{\star}$ & 1.000 & & & \\
\hline Question 5 & $0.549^{*}$ & $0.700^{*}$ & $0.526^{*}$ & $0.480^{*}$ & 1.000 & & \\
\hline Question 6 & $0.449^{*}$ & $0.727^{\star}$ & $0.709^{*}$ & $0.258^{*}$ & $0.512^{*}$ & 1.000 & \\
\hline Question 7 & $0.489^{*}$ & $0.618^{*}$ & $0.661^{*}$ & $0.335^{\star}$ & $0.628^{*}$ & $0.668^{*}$ & 1.000 \\
\hline
\end{tabular}

and a moderate but similar score between questions 6 and 7 ; therefore, model 3 was created considering an error variation (Fig. 4). Model 3 results did satisfactorily fit the recommended indices with the following results: $\chi^{2}=22.802(\mathrm{df}=13)$, with a chi-square/degrees of freedom ratio $(\mathrm{CMIN} / \mathrm{DF})=1.900(\mathrm{p}<0.001)$, $\mathrm{GFI}=0.972, \mathrm{CFI}=0.901, \mathrm{RMSEA}=0.062(95 \% \mathrm{Cl}$ : 0.019-0.100) and TLI = 0.827 (Table 5).

Subsequently, reliability was calculated, with adequate internal consistency being demonstrated in our population. Taking into account all seven questions of the scale, we found a Cronbach's $\alpha$-value of 0.870 .
Concurrency validity was estimated by contrasting it with HADS as in the original version. To measure FCV19S Spanish language version external validity, Pearson's correlation coefficient was used as a concurrent measure using HADS, with a positive and statistically significant correlation being found (Pearson's rho = $0.508, p<0.001$ ) using all seven questions (Table 6).

\section{Discussion}

This study analyzed FCV-19S Spanish language version psychometric properties in the Mexican general 
Table 4. Factor matrix without rotation

\begin{tabular}{|l|l|l|}
\hline Variable & F1 & Communality \\
\hline Question 1 & 0.640 & 0.410 \\
\hline Question 2 & 0.869 & 0.755 \\
\hline Question 3 & 0.788 & 0.621 \\
\hline Question 4 & 0.519 & 0.269 \\
\hline Question 5 & 0.768 & 0.590 \\
\hline Question 6 & 0.776 & 0.602 \\
\hline Question 7 & 0.784 & 0.615 \\
\hline
\end{tabular}

Table 5. Goodness-of-fit indices of the confirmatory factor analysis to test the suitability of a single factor model of the fear of COVID-19 scale Spanish language version

\begin{tabular}{|l|l|l|l|}
\hline & Model 1 & Model 2 & Model 3 \\
\hline Chi-square & 40.489 & 30.897 & 22.802 \\
\hline $\mathrm{p}$ & 0.000 & 0.003 & 0.029 \\
\hline CMIN-DF & 2.892 & 2.377 & 1.900 \\
\hline GFI & 0.951 & 0.962 & 0.972 \\
\hline TLI & 0.637 & 0.736 & 0.827 \\
\hline CFI & 0.768 & 0.836 & 0.901 \\
\hline RMSEA & 0.090 & 0.077 & 0.062 \\
\hline
\end{tabular}

CMIN-DF: Chi-square-degrees of freedom ratio; GFI: goodness of fit index

TLI: Tucker-Lewis index; CFI: comparative fit index; RMSEA: root mean square error of approximation.

population. Regarding the representativeness of the sample, in INEGl's recent data on sociodemographic characteristics of the Mexican population, we observed similarity in mean age, since $41.1 \%$ of participants were between 18 and 29 years of age, and $44.4 \%$ between 30 and 39 years; the high educational level in our sample $(41.1 \%)$ contrasts with $21.6 \%$ in the general population of our country; however, it is closer to the specific level in Mexico City ${ }^{5}$, where $34.6 \%$ of the population has college education, which could reflect the social and cultural differences that prevail in our country.

Regarding internal consistency, our result of $\alpha=0.870$ is similar to the validations carried out for other languages such as Italian $(\alpha=0.87)^{12}$, Russian $(\alpha=0.81)^{13}$, Turkish $(\alpha=0.85)^{14}$, Arabic $(\alpha=0.88)^{15}$, Hebrew $(\alpha=0.86)^{16}$, Bengali $(\alpha=0.87)^{17}$, Malayan $(\alpha=0.89)^{18}$, Romanian $(\alpha=0.88)^{19}$, Portuguese $(\alpha=0.88)^{20}$,

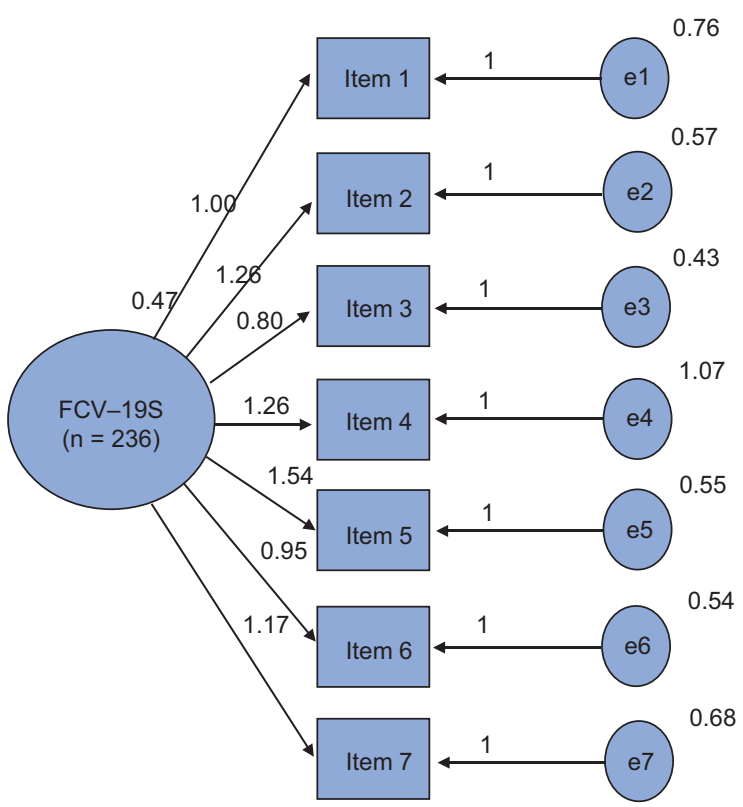

Figure 2. Baseline model 1 without covariance correlation. FCV-19S: Fear of COVID-19 scale.

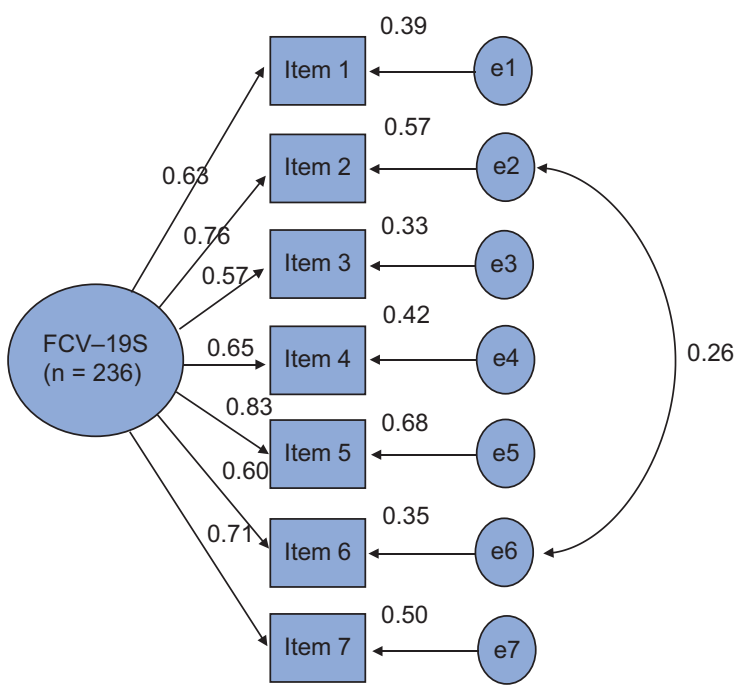

Figure 3. Model 2 with covariance correlation between questions 3 and 6.

Japanese $(\alpha=0.87)^{21}$, Greek $(\alpha=0.83)^{22}$ and English $(\alpha=0.84 \text { and } 0.86 \text { in different samples })^{23}$.

Our results are similar to those of validations carried out in Spanish in other contexts such as the Peruvian population $(\alpha=0.87)^{24}$ and Spanish university students $(\alpha=0.86)^{25}$.

FCV-19S mean total score in our population was $17.6 \pm 6.6$, similar to Italians $16.8 \pm 6.6^{12}$ and Russians $17 \pm 4.7^{13}$. In addition, as regards gender, we 


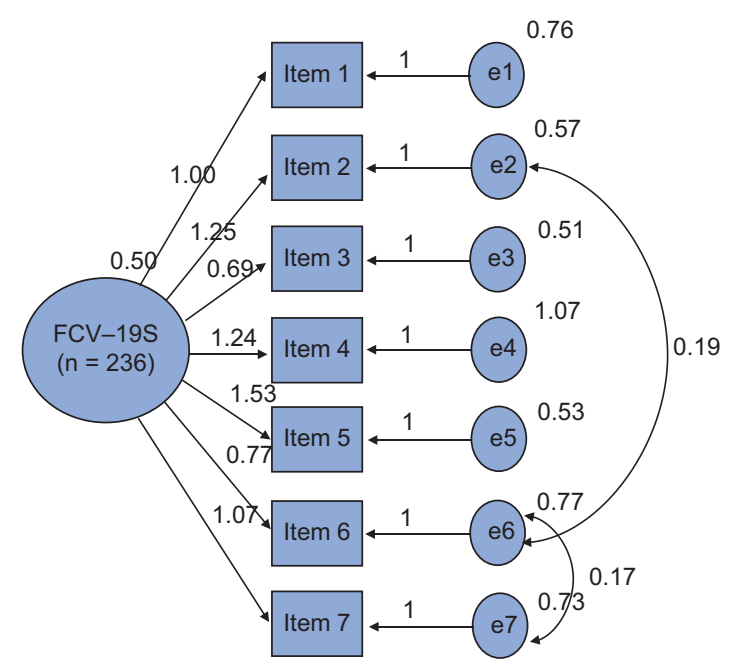

Figure 4. Model 3 with covariance correlation between questions 3, 6 and 7.

Table 6. Agreement measurements

\begin{tabular}{|c|c|c|c|c|c|}
\hline & & & Test & Retest & $\begin{array}{l}\text { Total } \\
\text { HADS }\end{array}$ \\
\hline \multirow[t]{3}{*}{ Pearson } & Test & $\begin{array}{l}\text { Correlation coefficient } \\
\text { Sig. (2-tailed) } \\
n\end{array}$ & $\begin{array}{c}1.00 \\
0.000 \\
306\end{array}$ & $\begin{array}{c}0.520^{*} \\
0.000 \\
306\end{array}$ & $\begin{array}{c}0.213^{*} \\
0.000 \\
306\end{array}$ \\
\hline & Retest & $\begin{array}{l}\text { Correlation coefficient } \\
\text { Sig. (2-tailed) } \\
n\end{array}$ & $\begin{array}{c}0.508^{*} \\
0.000 \\
306\end{array}$ & $\begin{array}{c}1.00 \\
0.000 \\
306\end{array}$ & $\begin{array}{c}0.151^{*} \\
0.008 \\
306\end{array}$ \\
\hline & $\begin{array}{l}\text { Total } \\
\text { HADS }\end{array}$ & $\begin{array}{l}\text { Correlation coefficient } \\
\text { Sig. (2-tailed) } \\
\text { n }\end{array}$ & $\begin{array}{c}0.213^{*} \\
0.000 \\
306\end{array}$ & $\begin{array}{c}0.151^{*} \\
0.008 \\
306\end{array}$ & $\begin{array}{c}1.00 \\
0.000 \\
306\end{array}$ \\
\hline
\end{tabular}

observed significant differences between women (19.09 \pm 6.67$)$ and men (14.99 \pm 5.62$)$, which is similar to the findings in other populations such as those from Bangladesh (women $22.75 \pm 5.65$ and men $20.29 \pm$ $5.90)^{17}$ or Russia (women $17.7 \pm 4.6$ and men $15.8 \pm$ 4.6) ${ }^{13}$. Total score reported for FCV-19S was higher in women, which is consistent with international reports on mental health, with a higher prevalence of anxiety and depression disorders being observed in women.

Regarding the factor load, the elements of our version (range: $0.519-0.869$ ) were similar to those of others, such as the Italian $(0.68-0.90)^{12}$, Arabic $(0.62-0.84)^{15}$, Bengali $(0.72-0.80)^{17}$ and the Peruvian version in the single factor model $(0.595-0.766)^{24}$.

In fact, on the confirmatory factor analysis, our results for CFI of 0.901 and RMSEA of 0.062 (95\%
Cl: 0.019-0.100) are comparable to those of other versions that used a single factor model with correlation in several elements, such as the Arabic $(\mathrm{CFI}=0.995, \mathrm{RMSEA}=0.059,95 \% \mathrm{Cl}: 0.037-$ $0.083)^{15}$, the Bengali $(\mathrm{CFI}=0.964 \text {, RMSEA }=0.071)^{17}$ and the Italian version $(\mathrm{CFI}=0.99$, RMSEA $=0.069$, 95\% Cl: 0.032-0.105) ${ }^{12}$.

In our population, the lowest scores were found in questions 3, 6 and 7, which assess somatic symptoms such as palmar hyperhidrosis, insomnia and palpitations, which is similar to the findings in other populations such as the Italian ${ }^{12}$, Turkish $^{14}$ or Bengali ${ }^{17}$.

Therefore, it is important for a cultural validation and adaptation to be carried out on each population, taking into account gender and age differences in order to reflect the reality of each sociocultural context, and thus allow a reliable measurement of COVID-19-related fear.

FCV-19S Spanish version validation for application in the Mexican population shows that it is a short instrument, easy to apply and interpret, which allows a screening for identifying individuals at risk of developing anxiety and depression disorders in order to start timely treatment.

\section{Strengths and limitations}

Initially, participants were reluctant to take part in the study, which we associate with the sociocultural context in our country, where mental health care is not a priority.

As a limitation, we recognize that the general sample can be considered representative, although heterogeneous given the age, gender, educational level and marital status; we are aware that no formal approach was followed for addressing this.

On the other hand, this analysis did not include previous diagnoses of mental disorders such as depression, anxiety or personality disorders, which in subsequent studies should be taken into account by recognizing subgroups with higher vulnerability when confronted with stressful situations. At the same time, it is a cross-sectional study, and subsequent longitudinal follow-up could therefore be quite enriching. Despite these limitations, this study shows useful information on the use of FCV-19S in its Spanish language version for application in the general population of Mexico. In addition, we consider it essential for a subsequent analysis to be carried out on health workers who participate in COVID response teams, given that they are in close 
contact with patients, with the purpose to validate its specific use in this population group.

\section{Conclusion}

The FCV-19S Spanish language version showed adequate reliability and internal consistency, as well as a good correlation in the score of the same measurements and subsequent correlation with HADS, thus confirming our analysis convergent validity. In addition, the results obtained are similar to those reported by other studies in Spanish-speaking populations, which suggests that it is an adequate scale with adequate psychometric properties for initial detection in the general population of Mexico.

\section{Acknowledgments}

The authors thank Susan Drier-Jonas for her support with the manuscript.

\section{Funding}

This research has not received any specific grant from agencies of the commercial, public or non-profit sectors.

\section{Conflict of interests}

The authors have no conflicts of interest to declare.

\section{Ethical disclosures}

Protection of human and animal subjects. The authors declare that no experiments were performed on humans or animals for this research.

Confidentiality of data. The authors declare that they have followed the protocols of their work center on the publication of patient data.

Right to privacy and informed consent. The authors have obtained informed consent from the patients and/or subjects referred to in the article. This document is in the possession of the corresponding author.

\section{References}

1. World Health Organization. WHO Director-General's opening remarks at the media briefing on COVID-19 - 11 March 2020 [Internet]. World Health Organization; 2020 [accessed: March 15, 2020]. Available at: https://www.who.int/dg/speeches/detail/who-director-general-sopening-remarks-at-the-media-briefing-on-covid-19---11march-2020
2. Dirección General de Epidemiología, Secretaría de Salud de México. Covid-19 México. Información General [Internet]. Mexico: Dirección General de Epidemiología, Secretaría de Salud; 29 de enero de 2021 [accessed: 18 March 2021]. Available at: https://datos.covid-19.conacyt.mx

3. Instituto Nacional de Estadística y Geografía. Características de las defunciones registradas en México durante enero a agosto de 2020 [Internet]. Mexico: Instituto Nacional de Estadística y Geografía (INEGI), Press release no. 61/21; January 27, 2021 [accessed: 18 March 2021]. Available at: https://www.inegi.org.mx/contenidos/ saladeprensa/boletines/2021/EstSociodemo/DefuncionesRegistradas2020_Pnles.pdf

4. Dirección General de Epidemiología, Secretaría de Salud. Informe semanal para la vigilancia epidemiológica de muertes maternas (4 de enero de 2021-semana epidemiológica 53) [Internet]. Mexico: Dirección General de Epidemiología, Secretaría de Salud [accessed: 18 March 2021]. Available at: https://www.gob.mx/salud/documentos/informes-semanales-para-la-vigilancia-epidemiologica-de-muertes-maternas-2020. Accessed: March 18, 2021.

5. Instituto Nacional de Estadística y Geografía. Panorama sociodemográfico de México. Censo de Población y Vivienda 2020 [Internet]. Mexico: Instituto Nacional de Estadística y Geografía (INEGI); January 2021 [accessed: 18 March 2021]. Available at: https://www.inegi.org.mx

6. Li YC, Bai WZ, Hashikawa T. The neuroinvasive potential of SARS-CoV2 may play a role in the respiratory failure of COVID-19 patients. J Med Virol. 2020;92(6):552-5.

7. Moreno C, Wykes T, Galderisi S, Nordentoft M, Crossley N, Jones N. How mental health care should change as a consequence of the COVID-19 pandemic. Lancet Psychiatry. 2020;7(9):813-24.

8. Ahorsu DK, Lin CY, Imani V, Saffari M, Griffiths MD, Pakpour AH. The fear of COVID-19 scale: Development and initial validation. Int J Ment Health Addict. 2020 Mar 27:1-9. doi: 10.1007/s11469-020-00270-8. Online ahead of print.

9. Soraci P, Ferrari A, Abbiati FA, del Fante E, de Pace R, Urso A, et al. Validation and psychometric evaluation of the Italian Version of the Fear of COVID-19 Scale. Int J Ment Health Addict. 2020 May 4;1-10. doi: 10.1007/s11469-020-00277-1. Online ahead of print.

10. Reznik A, Gritsenko V, Konstantinov V, Khamenka N, Isralowitz R. COVID19-fear in Eastern Europe: Validation of the Fear of COVID-19 Scale. Int J Ment Health Addict. 2020 May 12:1-6. doi: 10.1007/s11469020-00283-3. Online ahead of print.

11. Haktanir A, Seki T, Dilmac B. Adaptation and evaluation of Turkish Fear of COVID-19 Scale. Death Stud. 2020;29:1-9.

12. Alyami M, Henning M, Krägeloh $C$, Alyami H. Psychometric evaluation of the Arabic version of the Fear of COVID-19 Scale. Int J Ment Health Addict. 2020 May 16:1-14. doi: 10.1007/s11469-020-00316-x. Online ahead of print.

13. Tzur BD, Grossman GA, Bloch Y, Mayer Y, Shiffman N, Mendlovi S. Fear of COVID-19 scale. Psychometric characteristics, reliability and validity in Israeli population. Psychiatry Res. 2020;289:113100.

14. Sakib N, Bhuiyan AKMI, Hossain S, Al Mamun F, Hosen I, Hasnat Abdullah A, et al. Psychometric validation of the Bengla Fear of COVID-19 Scale Confirmatory Factor Analysis and Rasch Analysis. Int J Ment Health Addict. 2020 May 11:1-12. doi: 10.1007/s11469-020-00289-x. Online ahead of print.

15. Pang NTP, Kamu A, Hambali NLB, Mun HC, Kassim MA, Mohamed NH, et al. Malay version of the Fear of COVID-19 Scale: Validity and reliability. Int J Ment Health Addict. 2020 Jul 3:1-10. doi: 10.1007/s11469-02000355-4. Online ahead of print.

16. Stănculescu E. Fear of COVID-19 in Romania: Validation of the Romanian version of the Fear of COVID-19 Scale using graded response model analysis. Int J Ment Health Addict. 2021 Jan 6;1-16. doi: 10.1007/ s11469-020-00428-4. Online ahead of print.

17. Magano J, Vidal DG, Sousa HFPE, Dinis MAP, Leite Â. Validation and psychometric properties of the Portuguese version of the Coronavirus Anxiety Scale (CAS) and Fear of COVID-19 Scale (FCV-19S) and associations with travel, tourism and hospitality. Int $\mathrm{J}$ Environ Res Public Health. 2021:18(2):E427.

18. Wakashima K, Asai K, Kobayashi D, Koiwa K, Kamoshida S, Sakuraba M. The Japanese version of the Fear of COVID-19 Scale: Reliability, validity, and relation to coping behavior. PLoS One. 2020;15(11):e0241958.

19. Nikopoulou VA, Holeva V, Parlapani, E, Karamouzi P, Voitsidis P, Porfyri GN, et al. Mental health screening for COVID-19: a proposed cutoff score for the Greek version of the Fear of COVID-19 Scale (FCV-19S). 2020 Nov 10:1-14. doi: 10.1007/s11469-020-00414-w. Online ahead of print.

20. Winter T, Riordan BC, Pakpour AH, Griffiths MD, Mason A, Poulgrain JW, et al. Evaluation of the English Version of the Fear of COVID-19 Scale and Its relationship with behavior change and political beliefs. Int J Ment Health Addict. 2020 Jun 15;1-11. doi: 10.1007/s11469-020-00342-9. Online ahead of print.

21. Huarcaya-Victoria J, Villareal-Zegarra D, Podesta A, Luna-Cuadros MA Psychometric Properties of a Spanish Version of the Fear of COVID-19 Scale in General Population of Lima, Peru. Int J Ment Health Addict. 2020 Jun 22:1-14. doi: 10.1007/s11469-020-00354-5. Online ahead of print. 
22. Martínez- Lorca M, Martínez-Lorca A, Criado-Álvarez JJ, Cabañas Armesilla MD, Latorre JM. The fear of COVID-19 scale: Validation in Spanish university students. Psychiatry Research. 2020;293:113350.

23. García-Reyna, B, Castillo-García, GB, Barbosa-Camacho, FJ, Cervantes-Cardona GA, Cervantes-Pérez E, Torres-Mendoza BM, et al. Fear of COVID-19 Scale for Hospital Staff in Regional Hospitals in México: a brief report. Int J Ment Health Addict. 2020 Nov 4:1-12. doi: 10.1007/ s11469-020-00413-x. Online ahead of print.
24. Zigmond AS, Snaith RP. The Hospital Anxiety and Depression Scale. Acta Psychiatrica Scandinavica. 1983;67(6):361-70.

25. Villegas Pérez GC. Reporte de experiencia profesional. Tesis de maestría en Psicología. Mexico: Facultad de Psicología, Universidad Nacional Autónoma de México; 2004.

26. Vázquez GO, Benjet C, Juárez GF, Rojas CE, Riveros RA, Aguilar PJL, et al. Propiedades psicométricas de la Escala Hospitalaria de Ansiedad y Depresión en una población de pacientes oncológicos mexicanos. Salud Ment. 2015;38(4):253-8. 